\title{
PERANAN ASAS KESEIMBANGAN DALAM MEWUJUDKAN TUJUAN PERJANJIAN
}

\author{
Oleh : \\ Niru Anita Sinaga \\ Dosen Tetap Fakultas Hukum Universitas Dirgantara Marsekal Suryadarma Jakarta. \\ Ketua LKBH Fakultas Hukum Unsurya \\ Email : (anita_s1naga@yahoo.com) \\ dan
}

Tiberius Zaluchu

Email : (tiber.zaluchu@gmail.com)

\begin{abstract}
:
Man in fulfilling his various interests perform various ways, one of them by making a covenant. It is therefore necessary to understand important matters relating to a treaty, such as: What is the agreement, the terms of the agreement, the principles of the agreement, the object of the agreement, the terms of the agreement, the form of the agreement, the parties involved, the right and the obligations of the parties, the structure and the anatomy of the agreement, the settlement of disputes and the termination of the agreement. Article 1313 of the Civil Code states: The Covenant is an act by which one or more persons commit themselves to one or more persons. In general, the agreement is: The parties' agreement on something that gives birth to a legal relationship, creates rights and obligations, if not executed as the promised will impose sanctions. In order for what is promised to run well then required a regulating rule, called the law of agreement. The purpose of the treaty is to protect the parties in the event of future problems, order, is used as the basis for its settlement or legal certainty so as to create justice for the parties. In the making of the treaty, several important matters must be considered, among others: the terms of the validity of the agreement, the principles of the contractual law, the consequences of the law of agreement and the termination of the agreement. One of the most important principles in the agreement is the principle of equilibrium. However, in practice it is often not in accordance with the objectives of the agreement, among others: The existence of protection for the parties, the creation of justice, order, and legal certainty. The discussion in this research is about: What things should be considered or fulfilled to realize the achievement of the purpose of the agreement and How the role of the principle of balance in realizing the purpose of the agreement. The method used is normative juridical. In the event of a dispute concerning the treaty, it should be settled not only based on what is written in the agreement but taking into account the principles contained in the treaty law, especially the principle of equilibrium.
\end{abstract}

\section{Keywords: Balance Principle and Objectives of the Agreement}

\section{Abstrak :}

Manusia dalam memenuhi berbagai kepentingannya melakukan berbagai macam cara, salah satu diantaranya dengan membuat perjanjian. Oleh karena itu perlu pemahaman tentang hal-hal penting yang berhubungan dengan suatu perjanjian, antara lain: Apa itu perjanjian, syarat-syarat sahnya 
perjanjian, asas-asas perjanjian, objek perjanjian, jangka waktu perjanjian, bentuk perjanjian, para pihak yang terlibat, hak dan kewajiban para pihak, struktur dan anatomi pembuatan perjanjian, penyelesaian perselisihan dan berakhirnya perjanjian. Pasal 1313 KUHPerdata menyatakan: Perjanjian adalah suatu perbuatan dengan mana satu orang atau lebih mengikatkan dirinya terhadap satu orang lain atau lebih. Secara umum perjanjian adalah: Kesepakatan para pihak tentang sesuatu hal yang melahirkan perikatan/hubungan hukum, menimbulkan hak dan kewajiban, apabila tidak dijalankan sebagai mana yang diperjanjikan akan menimbulkan sanksi. Agar apa yang diperjanjikan dapat berjalan dengan baik maka dibutuhkan aturan yang mengatur, yang disebut hukum perjanjian. Tujuan dibuatnya perjanjian adalah untuk melindungi para pihak apabila terjadi masalah dikemudian hari, ketertiban, digunakan sebagai dasar untuk penyelesaiannya atau kepastian hukum sehingga tercipta keadilan bagi para pihak. Dalam pembuatan perjanjian harus diperhatikan beberapa hal penting, antara lain: Syarat-syarat sahnya perjanjian, asas-asas hukum perjanjian, akibat hukum perjanjian dan berakhirnya perjanjian. Salah satu asas yang sangat penting dalam perjanjian adalah asas keseimbangan. Namun dalam pelaksanaannya sering tidak sesuai dengan tujuan perjanjian, antara lain: Adanya perlindungan bagi para pihak, terciptanya keadilan, ketertiban, dan kepastian hukum. Pembahasan dalam penelitian ini adalah tentang: Hal-hal apa saja yang harus diperhatikan atau dipenuhi untuk mewujudkan tercapainya tujuan perjanjian dan Bagaimana peranan asas keseimbangan dalam mewujudkan tujuan perjanjian. Metode yang digunakan adalah yuridis normatif. Apabila terjadi sengketa mengenai perjanjian, hendaklah diselesaikan tidak hanya didasarkan pada apa yang tertulis dalam perjanjian tetapi memperhatikan asas-asas yang terdapat dalam hukum perjanjian terutama asas keseimbangan.

\section{Kata kunci: Asas Keseimbangan dan Tujuan Perjanjian.}

\section{PENDAHULUAN}

\section{Latar Belakang}

Manusia dalam memenuhi berbagai kepentingannya melakukan berbagai macam cara, salah satu diantaranya dengan membuat perjanjian. Dalam KUH Perdata perjanjian diatur dalam Buku III ( Pasal 1233-1864) tentang Perikatan. Pasal 1313 KUHPerdata menyatakan: "Perjanjian adalah suatu perbuatan dengan mana satu orang atau lebih mengikatkan dirinya terhadap satu orang lain atau lebih". Suatu kontrak atau perjanjian memiliki unsur-unsur, yaitu pihak-pihak yang kompeten, pokok yang disetujui, pertimbangan hukum, perjanjian timbal balik, serta hak dan kewajiban timbal balik. Berdasarkan rumusan pengertian perjanjian yang telah dikemukakan diatas dapat disimpulkan bahwa perjanjian itu terdiri dari: Ada pihak-pihak; Ada persetujuan antara pihak-pihak; Ada prestasi yang akan di laksanakan; Ada bentuk tertentu lisan atau tulisan; Ada syarat-syarat tertentu sebagai isi perjanjian; Ada tujuan yang hendak di capai.

Para pihak yang terlibat di dalam perjanjian harus memperhatikan klausulaklausula yang telah disepakati. Perjanjian nantinya dapat digunakan sebagai dasar yang mengikat untuk menyelesaikan permasalahan diantara bagi para pihak. Oleh karena itu perlu pemahaman tentang hal-hal penting yang berhubungan dengan suatu perjanjian, antara lain: Apa itu perjanjian, syarat-syarat sahnya perjanjian, asas-asas perjanjian, objek perjanjian, jangka waktu perjanjian, bentuk perjanjian, para pihak yang terlibat, hak dan kewajiban para pihak, struktur dan anatomi pembuatan perjanjian, penyelesaian perselisihan dan berakhirnya perjanjian.

Secara umum perjanjian adalah: Kesepakatan para pihak tentang sesuatu hal yang melahirkan perikatan/hubungan hukum, menimbulkan hak dan kewajiban, 
apabila tidak dijalankan sebagai mana yang diperjanjikan akan ada sanksi. Perikatan adalah suatu hubungan hukum antara dua orang atau dua pihak berdasarkan mana pihak yang satu berhak menuntut sesuatu hal dari pihak yang lain dan pihak yang lainnya berkewajiban untuk memenuhi tuntutan itu". Dengan demikian suatu kesepakatan berupa perjanjian pada hakikatnya adalah mengikat, bahkan sesuai dengan Pasal 1338 ayat 1 KUHPerdata, kesepakatan ini memiliki kekuatan mengikat sebagai undang-undang bagi para pihak yang membuatnya. ${ }^{1} \quad$ Agar apa yang diperjanjikan dapat berjalan dengan baik maka dibutuhkan aturan yang mengatur, yang disebut hukum perjanjian.

Dalam praktek dibutuhkan adanya suatu aturan sebagai pedoman mulai saat hendak membuat kerjasama atau bisnis, pada saat menjalankan dan juga sesudah pelaksanaan bisnis tersebut. Aturan yang akan dijadikan sebagai dasar yang mengikat bagi para pihak dibuat dalam bentuk perjanjian. Pembuatan suatu perjanjian hendaklah memperhatikan halhal penting, antara lain: Syarat-syarat sahnya perjanjian, prinsip-prinsip atau asas-asas perjanjian, hak dan kewajiban para pihak, struktur dan anatomi pembuatan kontrak, penyelesaian perselisihan dan berakhirnya kontrak.

Pasal 1320 KUHPerdata menentukan 4 syarat sahnya perjanjian, yaitu: ${ }^{2}$ Adanya kesepakatan kedua belah pihak, kecakapan untuk melakukan perbuatan hukum, adanya objek perjanjian dan adanya kausa yang halal. Dalam suatu perjanjian selain harus memperhatikan

\footnotetext{
Huala Adolf, Dasar-dasar Hukum Kontrak Internasional, Bandung: Refika Aditama, 2006, hal. 15.

2 Salim H.S, Hukum Kontrak Teori dan Teknik Penyusunan Kontrak, Jakarta: Sinar Grafika, 2010, hal. 33-34
}

syarat sahnya suatu perjanjian juga harus didasarkan pada beberapa asas atau prinsip umum yang terdapat pada hukum perjanjian, yaitu: Asas kebebasan berkontrak, asas konsensualisme, asas pacta sunt servanda, asas itikad baik asas kepribadian (personalitas). Juga asas atau prinsip lainnya yaitu: Asas kepercayaan, asas persamaan hukum, asas keseimbangan, asas kepastian hukum, asas moral, asas kepatutan, asas kebiasaan, dan asas perlindungan.

Dengan memperhatikan hal diatas maka diharapkan tujuan pembuatan perjanjian yaitu terciptanya keadilan, ketertiban, dan kepastian hukum dapat terwujud. Didalam perjanjian terkandung makna "janji harus ditepati" atau "janji adalah hutang". Dengan perjanjian diharapkan masingmasing individu akan menepati janji dan melaksanakannya. $^{3} \quad$ Dengan adanya perjanjian diharapkan pihak-pihak yang terlibat didalamnya dapat menjadikankan bisnis sesuai dengan kesepakatankesepakatan yang telah disetujui, melakukannya dengan keseimbangan dan sebagai dasar untuk menyelesaikan apabila timbul masalah dikemudian hari. Keseimbangan adalah suatu asas yang dimaksudkan untuk menselaraskan pranata-pranata hukum dan asas-asas pokok hukum perjanjian yang dikenal dalam hukum perdata yang berdasarkan pemikiran dan latar belakang individualisme pada suatu pihak dan cara pikir bangsa Indonesia pada lain pihak. ${ }^{4}$ Keseimbangan juga diartikan sebagai hal yang dilandaskan pada upaya mencapai suatu keadaan seimbang yang sebagai akibat dari itu harus memunculkan

\footnotetext{
${ }^{3}$ Reimon Wacks, Jurisprudence, London: Blackstones Press Limited , 1995, hal. 191.

${ }^{4}$ Herlin Boediono, Ajaran Umum Hukum Perjanjian dan Penerapannya Dibidang Kenotariatan Bandung: Citra Aditya, 2010, hal. 33
} 
pengalihan kekayaan secara $a^{3} s^{5}{ }^{5}$ Asas keseimbangan merupakan asas dalam Hukum Perjanjian Indonesia yang merupakan asas kelanjutan dari asas persamaan yang mengkehendaki keseimbangan hak dan kewajiban antara para pihak dalam perjanjian.

Namun dalam pelaksanaannya sering tidak berjalan dengan baik bahkan menimbulkan konflik. Hal semacam ini memerlukan sarana hukum untuk menyelesaikannnya. Eksistensi hukum sangat diperlukan untuk dihormati dan prinsip-prinsip hukum dijunjung tinggi. Prinsip-prinsip atau asas-asas dalam hukum berfungsi sebagai perlindungan kepentingan masyarakat. Harapan untuk menaati hukum dalam praktek hendaklah berjalan dengan baik.

Tolok ukur prinsip ini dapat dilihat sejauh mana para pihak mendapatkan perlindungan hukum apabila timbul masalah dalam pelaksannan perjanjian. Dalam penyelesaiannya masih sering tidak menerapkan asas-asas perikatan yang baik yang diatur dalam hukum perjanjian. Untuk mengatasi permasalahan tersebut, maka dibutuhkan adanya solusi agar tercipta apa yang menjadi tujuan dari pembuatan perjanjian yaitu keadilan bagi para pihak. Hal ini dapat diwujudkan, antara lain dengan: Memberikan perlindungan bagi para pihak, terutama pihak yang dirugikan. Asas keseimbangan merupakan asas yang sangat mendasar dalam hukum perjanjian untuk mewujudkan keadilan. Oleh karenanya pihak yang dirugikan harus dilindungi, dengan cara pihak yang telah melakukan wanprestasi harus menanggung akibat/konsekuensi yuridis yaitu haruslah menanggung akibat atau hukuman berupa.
Asas keseimbangan dijadikan sebagai landasan seseorang melakukan perbuatan hukum dalam membuat suatu perjanjian. Dengan asas ini para pihak harus melaksanakan substansi kontrak berdasarkan keseimbangan. Asas keseimbangan merupakan faktor penting sehingga pihak yang yang dirugikan akan mendapat perlindungan hukum secara wajar. Dengan latar belakang yang telah diuraikan diatas, penulis ingin mengetahui dan membahas lebih dalam tentang peranan asas keseimbangan dalam mewujudkan tujuan perjanjian, dalam penelitian yang berjudul: "PERANAN ASAS KESEIMBANGAN DALAM MEWUJUDKAN TUJUAN PERJANJIAN"

\section{Rumusan Masalah}

Dari latar belakang yang telah diuraikan diatas dirumuskan 2 permasalahan sebagai berikut:

1. Hal-hal apa saja yang harus diperhatikan atau dipenuhi untuk mewujudkan tercapainya tujuan perjanjian?

2. Bagaimana peranan asas keseimbangan dalam mewujudkan tujuan perjanjian?

\section{Tujuan dan Manfaat Penelitian}

Berdasarkan latar belakang dan pokok permasalahan diatas, tujuan dan manfaat penelitian adalah sebagai berikut:

\section{Tujuan Penelitian}

1. Untuk mengetahui dan menjelaskan hal-hal apa saja yang harus diperhatikan atau dipenuhi untuk mewujudkan tercapainya tujuan perjanjian.

2. Untuk mengetahui dan menjelaskan bagaimana peranan asas keseimbangan dalam mewujudkan tujuan perjanjian.

\footnotetext{
${ }^{5}$ Herlien Boediono, Azas Keseimbangan bagi Hukum Perjanjian Indonesia: Hukum Perjanjian Berlandaskan azas-azas Wigayati Indonesia, Op.Cit., hal. 316.
} 


\section{Manfaat Penelitian}

\section{Manfaat teoritis:}

1. Penelitian ini diharapkan dapat memberikan pemikiran dalam pengembangan khasanah ilmu pengetahuan khususnya kepada materi yang menyangkut hukum perjanjian secara umum dan masalah peranan asas keseimbangan dalam mewujudkan tujuan perjanjian.

2. Bahwa apabila timbul masalah dalam suatu perjanjian, maka asas keseimbangan dapat digunakan sebagai landasan untuk menyelesaikannya. Sehingga keadilan bagi para pihak dapat ditegakkan sesuai dengan ketentuan yang berlaku.

\section{Manfaat praktis:}

1. Penelitian ini diharapkan dapat memberikan masukan-masukan kepada regulator atau pemerintah khususnya dalam membuat regulasi yang berkaitan dengan perjanjian guna mewujudkan tujuan perjanjian dengan menerapkan keselarasan asas keseimbangan dengan seluruh asas hukum perjanjian lainnya.

2. Penelitian ini berguna untuk menambah wawasan dengan memberikan gambaran bagi pembaca terutama dibidang hukum, baik para mahasiswa fakultas hukum maupun masyarakyat tentang pentingnya penerapan asas keseimbangan dalam perjanjian serta implikasinya terhadap penyelesaian masalah yang timbul berkaitan dengan perjanjian sehingga dapat mewujudkan tujuan dari perjanjian yaitu keadilan bagi para pihak.

\section{Metode Penelitian}

Penelitian ini menggunakan pendekatan yuridis normatif yaitu dengan menginventarisasi, mengkaji dan menganalisis serta memahami hukum sebagai perangkat peraturan atau normanorma positif di dalam sistem perundangundangan yang mengatur mengenai kehidupan manusia ${ }^{6}$. Spesifikasi Penelitian ini adalah penelitian deskriptif analitis yang merupakan penelitian untuk menggambarkan alur komunikasi ilmiah dan menganalisa masalah yang ada yang akan disajikan secara deskriptif). ${ }^{7} J e n i s$ data yang digunakan adalah data sekunder. Data sekunder adalah antara lain mencakup bahan-bahan pustaka yang terkait penelitian, data sekunder mencakup: bahan hukum primer, bahan hukum sekunder dan bahan hukum tersier. ${ }^{8}$ Pengumpulan data dalam penelitian ini dilakukan melalui studi pustaka. Studi pustaka merupakan penelaahan terhadap bahan-bahan pustaka yang berkaitan dengan permasalahan yang diteliti. Data dianalisis secara normatifkualitatif.

\section{Kerangka teori}

Kerangka teori adalah pemikiran atau butir-butir pendapat, teori, tesis mengenai suatu kasus atau permasalahan yang dapat menjadi bahan perbandingan dan pegangan teoritis. Hal mana dapat menjadi masukan eksternal bagi penulis. ${ }^{9}$ Pada hakikatnya, teori merupakan serangkaian proposisi atau keterangan yang saling berhubungan dan tersusun dalam sistem deduksi, yang mengemukakan penjelasan atas sesuatu gejala. ${ }^{10}$ Umumnya terjadi tiga

\footnotetext{
${ }^{6}$ Soerjono Soekanto, Penelitian Hukum Normatif, Jakarta: PT Raja Grafindo Persada, 2003, hal. 13.

${ }^{7}$ Ibid, hal. 30.

${ }^{8} \mathrm{Ibid}$, hal. 13

9 M Solly Lubis, Filsafat Ilmu dan Penelitian, Bandung: Mandar Maju,1994, hal. 80.

10 Sri Gambir Melati Hatta, Beli Sewa Sebagai Perjanjian Tak Bernama: Pandangan Masyarakat dan Sikap Mahkamah Agung Indonesia, Bandung: alumni,
} cetakan ke-2, 2000, hal.16. 
elemen dalam suatu teori. Pertama, penjelasan tentang hubungan antar berbagai unsur dalam suatu teori. Kedua, teori menganut sistem deduktif, yaitu sesuatu yang bertolak dari suatu yang umum (abstrak) menuju suatu yang khusus dan nyata. Ketiga, bahwa teori memberikan penjelasan atas segala yang dikemukakannya. Dengan demikian, untuk kebutuhan penelitian, maka fungsi teori adalah mempunyai maksud/tujuan untuk memberikan pengarahan kepada penelitian yang akan dilakukan. ${ }^{11}$

\section{a. Grand Theory: Teori keadilan}

Hukum perjanjian lahir dari pemikiran untuk memberi keadilan bagi para pihak.

\section{b. Midle Range Theory: Keseimbangan}

Pelaksanaan perjanjian harus dilakukan dengan asas keseimbangan. Asas keseimbangan dalam perjanjian merupakan unsur penting, sekaligus sebagai upaya penegakan hukum dibidang perjanjian.

\section{c. Applied Theory: Teori Perlindungan}

Agar tujuan dibidang perjanjian dapat diwujudkan salah satu caranya adalah dengan jalan melindungi para pihak melalui sarana hukum yang ada.

\section{HASIL PENELITIAN DAN PEMBAHASAN}

\section{A. Pengertian Perjanjian Dan Hukum Perjanjian.}

Manusia dalam memenuhi berbagai kepentingannya melakukan berbagai macam cara, salah satu diantaranya dengan membuat perjanjian. Dalam

${ }^{11}$ Duane R. Monette Thomas J. Sullivan, Cornell R. Dejong, Aplied Social Research, Chicago, San Fransisco: halt, Reinhart and Winston Inc. 1989, hal.31.
KUH Perdata perjanjian diatur dalam Buku III ( Pasal 1233-1864) tentang Perikatan. BW menggunakan istilah kontrak dan perjanjian untuk pengertian yang sama. Hal ini dapat dilihat jelas dari judul Bab II Buku III BW yaitu: Tentang perikatanperikatan yang dilahirkan dari kontrak atau perjanjian. Dari judul tersebut dapat diberikan makna bahwa kontrak dan perjanjian dimaknai dengan pengertian yang sama. Pengertian tentang perjanjian atau kontrak beraneka ragam, antara lain:

Subekti mengatakan: Perjanjian adalah suatu peristiwa di mana seorang berjanji kepada seorang lain atau di mana dua orang itu saling berjanji untuk melaksanakan suatu hal. Sedangkan perikatan adalah perhubungan hukum antara dua orang atau dua pihak, berdasarkan mana pihak yang satu berhak menuntut sesuatu hal dari pihak yang lain, dan pihak yang lain berkewajiban untuk memenuhi tuntutan tersebut.

Pasal 1313 KUHPerdata menyatakan: "Perjanjian adalah suatu perbuatan dengan mana satu orang atau lebih mengikatkan dirinya terhadap satu orang lain atau lebih". ${ }^{12}$

Black's Law Dictionary merumuskan kontrak sebagai berikut: "an agreement betwen two or more persons which creates an obligation, to do or not to do a particular thing". Diartikan kontrak adalah perjanjian antara 2 orang atau lebih yang menciptakan kewajiban

${ }^{12}$ KUHPerdata, (Burgelijk Wetboek), diterjemahkan oleh R. Soebekti dan R. Tjitrisadibio, Jakarta : Pradya Paramita, cetakan 8, 1976, Pasal 1313, hal. 338. 
untuk melakukan atau tidak melakukan suatu tindakan tertentu". ${ }^{13}$

Untuk mengatur semua yang berhubungan dengan kontrak dibutuhkan suatu hukum yang disebut hukum kontrak.

Lawrence M. Friedman mengartikan hukum kontrak adalah: "Perangkat hukum yang hanya mengatur aspek tertentu dari pasar dan mengatur jenis perjanjian tertentu." 14

Salim H.S, mengatakan hukum kontrak adalah: "Keseluruhan dari dari kaidah-kaidah hukum yang mengatur hubungan hukum antara dua pihak atau lebih berdasarkan kata sepakat untuk menimbulkan akibat hukum".

Menurut Munir Fuady, Hukum binis adalah suatu perangkat kaidah hukum (termasuk enforcement-nya) yang mengatur tentang tatacara pelaksanaan urusan atau kegiatan dagang, industri atau keuangan yang dihubungkan dengan produksi atau pertukaran barang atau jasa dengan menempatkan uang dari para entrepreneur dalam risiko tertentu dengan usaha tertentu dengan motif (dari entrepreneur tersebut) adalah untuk mendapatkan keuntungan. ${ }^{15}$

Dari definisi diatas, dapat dikemukakan unsur-unsur yang tercantum dalam hukum perjanjian adalah: Adanya kaidah hukum, subjek hukum, adanya prestasi, kata sepakat,

${ }^{13}$ Henry Campbell Black, Black Law Dictionary, Sixth Edition, West Publishing Co, St. Paul Minn, 1990, hal. 322

14 Lawrence M. Friedman, American Law An Introduction, penerjemah Whisnu Basuki, Jakarta: Tata Nusa, 2001, hal. 196.

${ }^{15}$ Munir Fuady, Pengantar Hukum Kontrak (Menata Bisnis Moderndi Era Global), Edisi Revisi, Bandung: PT.Citra Aditya Bakti, 2005, hal. 2. akibat hukum. Dengan demikian suatu kesepakatan berupa perjanjian atau kontrak pada hakikatnya adalah mengikat, bahkan sesuai dengan Pasal 1338 ayat 1 KUHPerdata, kesepakatan ini memiliki kekuatan mengikat sebagai undang-undang bagi para pihak yang membuatnya. ${ }^{16}$

Berdasarkan rumusan pengertian perjanjian yang telah dikemukakan diatas dapat disimpulkan bahwa perjanjian itu terdiri dari: ${ }^{17} \mathrm{Ada}$ pihakpihak, ada persetujuan antara pihakpihak, ada prestasi yang akan di laksanakan, sebab yang halal, ada bentuk tertentu lisan atau tulisan, ada syarat-syarat tertentu sebagai isi perjanjian dan ada tujuan yang hendak di capai. Dalam pembuatan perjanjian ada beberapa hal penting yang harus diperhatikan, al: Sistem pengaturan hukum perjanjian, asas hukum perjanjian, syarat sahnya suatu perjanjian, bentuk dan jenis-jenis perjanjian.Tujuan dari perjanjian adalah sebagai sarana untuk mengatur pertukaran hak dan kewajiban diharapkan dapat berlangsung dengan baik, fair dan proporsional sesuai kesepakataan para pihak.

\section{B. Hal-Hal Yang Harus Diperhatikan Atau Dipenuhi Untuk Mewujudkan Tercapainya Tujuan Perjanjian.}

1. Sistem pengaturan hukum perjanjian.

Sistem Pengaturan hukum perjanjian adalah system terbuka (open system), artinya bahwa setiap orang bebas untuk mengadakan perjanjian, baik yang sudah diatur

${ }^{16}$ Huala Adolf, Op.Cit., hal. 15.

17 Sudikno Mertokusumo, Mengenal Hukum: Suatu Pengantar, Yogyakarta: Liberty, 1999, hal. 82. 
maupun yang belum diatur di dalam undang-undang.

Disimpulkan dari ketentuan yang tercantum dala pasal 1338 ayat (1) KUH Perdata, yang berbunyi "Semua perjanjian yang dibuat secara sah berlaku sebagai undangundang bagi mereka yang membuatnya". Dan memberi kebebasan kepada para pihak untuk: Membuat atau tidak membuat perjanjian; Mengadakan perjanjian dengan siapapun; Menentukan isi perjanjian, pelaksanaan, dan persyaratannya dan; Menentukan bentuknya perjanjian, yaitu tertulis atau lisan.

2. Asas hukum perjanjian

Selain syarat sahnya suatu perjanjian yang diatur dalam pasal 1320 KUHPerdata, dalam pelaksanaannya perjanjian juga harus memperhatikan dan menerapkan asas-asas dalam hukum perjanjian. ${ }^{18}$ Didalam hukum perjanjian dikenal asas-asas hukum perjanjian, yaitu:

a. Asas Konsensualisme. Asas konsensualisme mempunyai arti yang terpenting, bahwa untuk melahirkan perjanjian cukup dengan sepakat saja dan bahwa perjanjian itu (dan perikatan yang ditimbukanl karenanya) sudah dilahirkan pada saat atau detik tercapainya konsensus. Asas ini ditemukan dalam pasal 1320 KUH Perdata dan dalam pasal 3120 KUH Perdata.

${ }^{18}$ Anita Kamilah, Bangun Guna Serah (Build operate and Transferl BOT ) Membangun Tanpa Harus Memiliki Tanah (Persfektif Hukum Agraria, Hukum Perjanjian dan Hukum Publik), Bandung: CV Keni Media, 2013, hal. 97. b. Asas Kebebasan Berkontrak. Dapat dianalisis dari ketentuan pasal 1338 ayat(1) KUH Perdata yang berbunyi "semua perjanjian yang dibuat secara sah berlaku sebagai undangundang bagi mereka yang membuatnya". Berdasarkan Asas Kebebasan Berkontrak, maka orang pada asasnya dapat membuat perjanjian dengan isi yang bagaimanapun juga, asal tidak bertentangan dengan undang-undang, kesusilaan dan ketertiban umum.

c. Asas Kekuatan Mengikat Perjanjian (Asas Pacta Sun Servanda). Dengan kata lain perjanjian yang diperbuat secara sah berlaku seperti berlakunya undang-undang bagi para pihak yang membutnya (Pasal 1338 ayat(1) dan ayat (2) KUH Perdata. Berarti para pihak harus mentaati apa yang mereka sepakati bersama.

d. Asas itikad baik (Good faith). Dalam bahasa hukumnya disebut de goedetrow. Asas ini berkaitan dengan pelaksanaan suatu perjanjian. Mengenai asas itikad baik ini terdapat dalam pasal 1338 ayat (3) $\mathrm{KUH}$ Perdata yang menentukan"persetujuanpersetujuan harus dilaksanakan dengan itikad baik".

e. Asas kepercayaan. Tanpa adanya kepercayaan itu maka perjanjian itu tidak mungkin akan diadakan kedua belah pihak, dengan kepercayaan ini kedua pihak mengikatkan dirinya untuk keduanya prrjanjian itu mempunyai 
kekuatan mengikat sebagai undang-undang.

f. Asas personalitas. Asas ini merupakan asas pertama dalam hukum perjanjian yang pengaturannya dapat ditemukan dalam ketentuan pasal 1315 KUH Perdatya yang bunyinya" pada umumnya tak seorang pun dapat mengikatkan diri atas nama sendiri atau meminta ditetapkannya suatu janji selain untuk dirinya sendiri".

g. Asas persamaan hukum. Asas ini menempatkan para pihak didalam persamaan derajat dan tidak dibedabedakan baik dari warna kulitnya, bangsa, kekayaan, jabatan dan lain-lain.

h. Asas keseimbangan. Asas ini menghendaki kedua pihak memenuhi dan melaksanakan perjanjian itu. Asas keseimbangan ini merupakan kelanjutan dari asas persamaan.

i. Asas kepastian hukum. Perjanjian sebagai suatu figur hukum harus mengandung kepastian hukum. Kepastian ini terungkap dari kekuatan mengikat perjanjian itu yaitu sebagai undang-undang bagi para pihak.

j. Asas moral. Dimana seseorang yang melakukan perbuatan sukarela (moral) yang bersangkutan mempunyai kewajiban (hukum) untuk meneruskan dan menyelesaikan perbuatannya juga asas ini terdapat dalam pasal $1339 \mathrm{KUH}$ Perdata.

k. Asas kepatutan. Asas kepatutan disini barkaitan dengan ketentuan mengenai isi perjanjian.
1. Asas kebiasaan. Asas ini diatur dalam pasal 1339 jo. Pasal 1347 KUH Perdata, yang dipandang sebagai bagian dari perjanjian tidak hanya mengikat untuk apa saja yang secara tegas diatur, akan tetapi juga hal-hal yang dalam kebiasaan dan lazim diikuti.

m. Asas perlindungan.

Mengandung arti bahwa antara kreditur dan debitur harus dilindungi oleh hukum. Namun yang perlu mendapat perlindungan adalah pihak debitur karena piuhak ini berada pada posisi yang lemah.

Asas-asas inilah yang menjadi dasar pijakan daripada pihak dalam menentukan dan membuat suatu perjanjian dalam kegiatan hukum sehari-hari. Dengan demikian dapat dipahami bahwa dari keseluruhan asas tersebut diatas merupakan hal yang penting dan mutlak harus diperhatikan bagi para pembuat perjanjian sehingga tujuan akhir dari suatu kesepakatan dapat tercapai dan terlaksana sebagaimana diinginkan oleh para pihak.

3. Syarat sahnya suatu perjanjian Pasal $1320 \quad$ KUHPerdata menentukan empat syarat sahnya perjanjian, yaitu:

a. Adanya kesepakatan kedua belah pihak.

b. Kecakapan untuk melakukan perbuatan hukum.

c. Adanya objek perjanjian

d. Adanya causa yang halal.

Syarat pertama dan kedua disebut syarat subjektif karena menyangkut pihak-pihak yang mengadakan 
perjanjian. Syarat ketiga dan keempat disebut syarat objektif, karena menyangkut objek dari perjanjian. Apabila syarat pertama dan kedua tidak terpenuhi maka perjanjian dapat dibatalkan. Jika syarat ketiga dan keempat tidak terpenuhi maka perjanjian itu batal demi hukum artinya, bahwa dari semula perjanjian dianggap tidak pernah terjadi.

4. Bentuk dan jenis-jenis perjanjian. Bentuk perjanjian dapat dibedakan menjadi dua macam, yaitu tertulis dan lisan.

5. Istilah dan ketentuan yang harus diperhatikan dalam pembuatan perjanjian.

a. Somasi. Somasi diatur dalam pasal 1238 dan 1243 KUHPer. Somasi adalah teguran dari si berpiutang (kreditur) kepada si berutang (debitur) agar dapat memenuhi prestasi sesuai dengan isi perjanjian yang telah disepakati antara keduanya. Ada tiga cara terjadinya somasi itu, yaitu :

1) Debitur melaksanakan prestasi yang keliru, misalnya kreditur menerima sekeranjang jambu seharusnya sekeranjang apel.

2) Debitur tidak memenuhi prestasi pada hari yang telah dijanjikan.

3) Prestasi yang dilakukan oleh debitur tidak lagi berguna bagi kreditur setelah lewat waktu yang diperjanjikan.

b. Prestasi. Prestasi merupakan hal yang harus dilaksanakan dalam suatu perikatan.Pemenuhan prestasi merupakan hakikat dari suatu perikatan. c. Wanprestasi. Wanprestasi artinya tidak dipenuhinya prestasi atau kewajiban yang telah ditetapkan terhadap pihakpihak tertentu didalam suatu perikatan, baik perikatan yang dilahirkan dari suatu perjanjian ataupun perikatan yang timbul kerna undang-undang.

d. Ganti rugi. Ada dua sebab timbulnya ganti rugi, yaitu ganti rugi karena wanprestasi dan perbuatan melawan hukum. Ganti rugi karena wanprestai diatur dalam buku III KUHPer. Sedangkan ganti rugi karena perbuatan melawan hukum diatur dalam pasal 1365 KUHPer.

e. Keadaan memaksa. Keadaan memaksa adalah suatu keadaan dimana debitur tidak dapat melakukan prestasinya kepada kreditur, yang disebabkan adanya kejadian yang berada diluar kekuasaannya.Misalnya karena adanya gempa bumi, banjir bandang, lahar, dan lainlain.

\section{f. Risiko}

6. Hal-hal yang harus diperhatikan dalam pembuatan/ penyusunan perjanjian.

Pada dasarnya perjanjian yang dibuat oleh para pihak berlaku sebagai undang-undang bagi mereka yang membuatnya. Dengan demikian, perjanjian yang dibuat oleh para pihak disamakan dengan undang-undang. Oleh karena itu, untuk membuat perjanjian diperlukan ketelitian dan kecermatan dari para pihak.

1) Hal-hal yang diperhatikan oleh para pihak yang akan 
mengadakan dan membuat perjanjian: Kewenangan hukum para pihak; Perpajakan; Alas hak yang sah; Masalah keagrariaan; Pilihan hukum; Penyelesaian sengketa; Pengakhiran perjanjian, dan Bentuk perjanjian standar.

2) Prinsip-prinsip dalam penyusunan perjanjian

Prapenyusunan perjanjian. Sebelum perjanjian disusun, ada empat hal yang harus diperhatikan oleh para pihak, antara lain: Indentifikasi para pihak, Penelitian awal aspek terkait, Pembuatan memorandum of understanding (MOU), Negosiasi Tahap penyusunan. Pembuatan draf pertama, yang meliputi : Judul perjanjian, Pembukaan (biasanya berisi tanggal pembuatan perjanjian), Pihak-pihak dalam perjanjian, Racital (penjelasan resmi/latar belakang terjadinya suatu kontrak), Isi perjanjian (inti perjanjian (yang dikehendaki, hak, dan kewajiban), Penutup (tata cara pengesahan suatu perjanjian). Disini perlu: Saling menukar draf perjanjian, Jika perlu diadakan revisi, Dilakukan penyelesaian akhir, Penutup dengan penandatanganan kontrak oleh masing-masing pihak.

\section{Struktur dan anatomi kontrak}

a. Bagian pendahuluan: Subbagian pembuka; Subbagian pencantuman identitas para pihak (caption); Subbagian penjelasan

b. Bagian isi: Klausula definisi; Klausula transaksi; Klausula spesifik dan Klausula ketentuan umum c. Bagian penutup: Subbagian kata penutup dan Subbagian ruang penempatan tanda tangan

Pasca penyusunan perjanjian. Apabila perjanjian telah dibuat dan ditandatangani oleh para pihak, maka ada dua hal yang harus diperhatikan oleh para pihak, yaitu sebagai berikut

\section{Bentuk - bentuk penyelesaian} sengketa.

Pada dasarnya setiap perjanjian (perjanjian) yang dibuat para pihak harus dapat dilaksanakan dengan sukarela atau iktikad baik, namun dalam kenyataannya perjanjian yang dibuatnya seringkali dilanggar.Pola penyelesaian sengketa dapat dibagi menjadi dua macam, yaitu melalui pengadilan, dan alternative penyelesaian sengketa. Penyelesaian melalui pengadilan adalah suatu pola penyelesaian sengketa yang terjadi antara pihak yang diselesaikan oleh pengadilan. Putusannya bersifat mengikat. Sedangkan penyelesaian sengeketa melalui alternative penyelesaian sengketa (ADR) adalah lembaga pemyelesaian sengkea atau beda pendapat melalui prosedur yang disepakati para pihak, yakni penyelesaian di luar pengadilan dengan cara konsultasi, negosiasi, mediasi, konsiliasi, atau penilaian ahli.

\section{Berakhirnya Perjanjian}

Hapusnya suatu perikatan diatur dalam Bab IV Buku III KUHPerdata Pasal 1381 KUHPerdata, yaitu: Pembayaran, penawaran tunai disertai dengan penitipan, pembaharuan hutang, perjumpaan hutang, percampuran hutang, pembebasan hutang, musnahnya benda yang terhutang, kebatalan atau pembatalan, 
berlakunya syarat batal, kadaluarsa atau lewat waktu.

Menurut R. Setiawan ada beberapa cara yang dapat mengakibatkan berakhirnya suatu perjanjian, yaitu: ${ }^{19}$ Ditentukan dalam perjanjian oleh para pihak; Suatu perjanjian berakhir pada saat yang telah ditentukan oleh para pihak; Para pihak atau undangundang dapat menentukan bahwa dengan terjadinya peristiwa tertentu maka perjanjian akan hapus; Tujuan telah tercapai dan Dengan perjanjian para pihak (herroeping).

\section{Tujuan Pembuatan Perjanjian.}

Tujuan yang hendak di capai dalam perjanjian adalah isi dari perjanjian itu sendiri. Dalam menentukan isi perjanjian meskipun didasarkan atas kebebasan berkontrak akan tetapi tidak boleh bertentangan dengan ketertiban umum, kesusilaan dan tidak dilarang oleh undang-undang. Yang diperjanjiakan berupa: memberikan sesuatu, berbuat sesuatu, tidak berbuat sesuatu, maka masingmasing pihak berhak untuk menerima apa yang dijanjikan oleh pihak lain. Bagi pihak yang gagal melaksanakan sesuatu yang telah diperjanjikan, maka pihak lain dapat menggunakan otoritas lembaga pengadilan untuk melaksanakan kontrak tersebut bahkan untuk memperoleh ganti rugi atau pemulihan lain yang dimungkinkan oleh hukum".${ }^{20}$ Dengan memperhatikan hal diatas maka diharapkan tujuan pembuatan perjanjian yaitu terciptanya keadilan, ketertiban, dan kepastian hukum dapat terwujud.

Di dalam perjanjian terkandung makna "janji harus ditepati" atau "janji adalah hutang". Dengan perjanjian diharapkan masing-masing individu akan menepati janji dan melaksanakannya. ${ }^{21}$ Dengan adanya perjanjian diharapkan pihak-pihak yang terlibat didalamnya dapat menjadikankan bisnis sesuai dengan kesepakatan-kesepakatan yang telah disetujui, melakukannya dengan keseimbangan dan sebagai dasar untuk menyelesaikan apabila timbul masalah dikemudian hari.

\section{Peranan Asas Keseimbanga Dalam Mewujudkan Tujuan Perjanjian.}

Sejumlah asas hukum merupakan dasar bagi hukum perjanjian. Asasasas utama dianggap sebagai soko guru hukum perjanjian, memberikan sebuah gambaran mengenai latar belakang cara berpikir yang menjadi dasar hukum perjanjian. Satu dan lain karena sifat fundamental hal-hal tersebut, maka prinsip-prinsip utama itu dikatakan pula sebagai prinsipprinsip dasar. Asas hukum merupakan landasan yang paling luas bagi lahirnya suatu peraturan hukum. Ini berarti bahwa peraturan-peraturan hukum pada akhirnya bisa dikembalikan kepada asas-asas tersebut. $^{22}$ Asas berfungsi sebagai pedoman atau arahan orientasi berdasarkan mana hukum dapat dijalankan.
19 R.Setiawan, Pokok-pokok Hukum Perikatan, Bandung: Binacipta, 1978, hal. 24.

${ }^{20}$ Soejono Dirdjosisworo, Hukum Bisnis, Bandung: Mandar Maju, 2003, hal. 28.
${ }^{21}$ Reimon Wacks, Op. Cit., hal. 191.

${ }^{22}$ Johannes Ibrahim \& Lindawaty Sewu, Hukum Bisnis Dalam Persepsi Manusia Modern, Bandung: PT. Refika Aditama, Cetakan kedua, 2007, hal. 50. 
Asas keseimbangan adalah suatu asas yang dimaksudkan untuk menselaraskan pranata-pranata hukum dan asas-asas pokok hukum perjanjian yang dikenal dalam hukum perdata yang berdasarkan pemikiran dan latar belakang individualisme pada suatu pihak dan cara pikir bangsa Indonesia pada lain pihak. Keseimbangan juga diartikan sebagai hal yang dilandaskan pada upaya mencapai suatu keadaan seimbang yang sebagai akibat dari itu harus memunculkan pengalihan kekayaan secara absah. Asas keseimbangan merupakan asas dalam Hukum Perjanjian Indonesia yang merupakan asas kelanjutan dari asas persamaan yang mengkehendaki keseimbangan hak dan kewajiban antara para pihak dalam perjanjian. Masyarakat Indonesia yang didasarkan pada alam pikiran adat, mempunyai pandangan bahwa kebebasan yang dimiliki individu bukanlah kebebasan yang tanpa batas. Di dalam pandangan adat, individu tidak terpisahkan dari masyarakatnya. Ia ada dan baru bermakna sebagai individu berkat adanya masyarakat. Individu dan masyarakat tidak ditempatkan berhadapan satu sama lainnya, tetapi keduanya ditempatkan dalam keseimbangan dan keselarasan, yang tercermin dalam sifat-sifat masyarakat adat yang sangat menjunjung tinggi nilai-nilai ikatan kekerabatan dan kebersamaan, kekeluargaan, gotong royong, dan tolong menolong. ${ }^{23}$ Semangat gotong royong terungkap dalam kehidupan sehari-hari dalam bentuk kerjasama oleh semua dalam rangka mencapai tujuan kesejahteraan bersama. Didalamnya terdapat

${ }^{23}$ Anita Kamilah, Op.Cit., hal. 103. keselarasan (keseimbangan) bahwa kepentingan perseorangan terintegrasi ke dalam kepentingan bersama dan satu sama lainnya tidak terpisahkan. Kerjasama dalam ikatan gotong royong di atas merupakan pengejawantahan dari asas rukun. ${ }^{24}$

Cara pandang dan pemikiran masyarakat Indonesia di atas, terungkap dan terimplementasikan di dalam filosofi hukum Indonesia yang dikenal sebagai Pancasila yang merupakan "bahan dasar" (bouwstenen) untuk membangun asas keterikatan kontraktual baru yang akan melandasi hukum perjanjian Indonesia. ${ }^{25}$

Baik asas-asas hukum perjanjian yang hidup dalam kesadaran hukum Indonesia seperti semangat gorong royong, kekeluargaan, rukun, patut, pantas, dan harmonis, sebagaimana yang tercantum dalam hukum adat maupun asas-asas hukum perjanjian modern seperti asas konsensual, asas kebebasan berkontrak, asas itikad baik maupun asas pacta sunt servanda, sebagaimana ditemukan dalam perkembangan perundang-undangan hukum kontrak Belanda, paktik hukum, maupun yurisprudensi, bertemu dalam satu asas, yaitu "Asas Keseimbangan". ${ }^{26}$

Asas keseimbangan itu menyemangati dan sekaligus juga menjadi asas operasionalisasi dari asas hukum perjanjian, baik dari hukum perjanjian Indonesia maupun dari hukum perjanjian Belanda yang mewakili hukum modern. Dalam hukum

\footnotetext{
${ }^{24}$ Herlien Budiono, Azas Keseimbangan bagi Hukum Perjanjian Indonesia, Op. Cit., hal. 191.

${ }^{25}$ Anita Kamilah, Op.Cit., hal. 104.

${ }^{26}$ Herlien Budiono, Azas Keseimbangan bagi Hukum Perjanjian Indonesia, Op. Cit., hal. Vii.
} 
perjanjian Belanda, penerapan asas keseimbangan itu misalnya tampak dari keharusan untuk mengacu pada kesusilaan, itikad baik, kepatutan, dan kepantasan dalam melaksanakan hakhak dan kewajiban yang ditimbulkan dan suatu perjanjian. ${ }^{27}$ Oleh karena itu, asas keseimbangan dapat dipandang dan dioperasikan sebagai titik harmonisasi upaya pembangunan hukum perjanjian Indonesia pada tuntutan-tuntutan modern, yang membuka pintu dan menjadi saringan untuk menerima gagasan-gagasan atau pranata-pranata hukum modern yang berasal, baik dari lingkungan Civil Law Sistem maupun Common Law Sistem atau pun dari sistem hukum lainnya dan mengolahnya menjadi bagian dari sistem hukum nasional Indonesia, sehingga tercipta sistem hukum perjanjian nasional yang modern, dengan tetap mempertahankan ciri khas identitas bangsa Indonesia. ${ }^{28}$

Para pihak melakukan suatu perjanjian lazimnya dilandasi suatu tujuan atau maksud tertentu yang dilandaskan pada kehendak yang telah diungkapkan, yaitu dalam bentuk janji-janji di antara para pihak yang terkait. Di dalam dunia ekonomi, perjanjian merupakan instrumen yang terpenting untuk mewujudkan perubahan-perubahan ekonomi dalam pembagian barang dan jasa. Perjanjian memiliki tujuan untuk menciptakan keadaan yang lebih baik bagi kedua belah pihak. ${ }^{29}$ Dalam pandangan Atiyah, perjanjian memiliki tiga

${ }^{27}$ Anita Kamilah, Op.Cit., hal. 104.

${ }^{28}$ Ibid

${ }^{29}$ Ibid, hal 105. tujuan dasar, sebagaimana digambarkan di bawah ini: ${ }^{30}$

1. Memaksakan suatu janji dan melindungi harapan wajar yang muncul darinya,

2. mencegah pengayaan (upaya memperkaya diri) yang dilakukan secara tidak adil atau tidak benar,

3. To prevent certain kinds of harm.

Di samping ketiga tujuan yang disebutkan di atas, Herlien Budiono menambahkan tujuan keempat dari perjanjian yaitu mencapai keseimbangan. antara kepentingan sendiri dan kepentingan terkait dari pihak lawan, yang diturunkan dari asas laras (harmoni) di dalam hukum adat. $^{31}$ Penutupan suatu perjanjian yang berjalan sepenuhnya sebagaimana dikehendaki para pihak memberikan arti bahwa tujuan akhir perjanjian akan tercapai dan secara umum telah tercipta "kepuasaan", sehingga jiwa atau semangat keseimbangan sebagai suatu asas yang mengharmonisasikan pranata-pranata hukum dan asas-asas pokok hukum perjanjian yang ditemukan di dalam KUHPerdata pada satu pihak déngan cara berpikir bangsa Indonesia di pihak lain telah difungsikan. ${ }^{32}$

Kata seimbang "evenwicht", yang dimaknai dalam kehidupan sehari-hari menunjuk pada pengertian suatu keadaan pembagian beban di kedua sisi berada dalam keadaan seimbang. Keseimbangan pun dimengerti sebagai keadaan hening atau keselarasan karena dari berbagai gaya yang

${ }^{30}$ P.S Atiyah, An Introduction to the Law of Contract, 5th. Ed., New York: Oxford University Press Inc, 1995, hal. 35.

${ }^{31}$ Herlien Boediono, Azas Kesimbangan Bagi Hukum Perjanjian Indonesia, Op.Cit, hal. 310.

${ }^{32}$ Anita Kamilah, Op.Cit., hal. 105. 
bekerja tidak satu pun mendominasi yang lainnya, atau karena tidak ada satu elemen menguasai lainnya.

Menurut Soepomo tujuan keempat dari suatu perjanjian adalah mencapai keseimbangan, kepantasan, atau sikap sosial tertentu. Hal ini dimaksudkan untuk mencerminkan rasa syukur atau kepuasan dan upaya secara sadar untuk menggapai peluang eksistensi immateriil (immateriele zijnsmogelijkheid)

Atas hal tersebut, Rawls berpendapat bahwa:

Happiness (kepuasan batin) seperti diatas merupakan landasan dari asas the good of justice yang mencakup dua aspek yaitu; (.....) one is the succesfull execution of a rational plan (the schedule of activities and aims) which a person strives to realize, the other is his state of mind, his sure of confidence supported bye good reason that his succes will endure (....... $)^{33}$

Syarat keseimbangan sebagai tujuan keempat dicapai melalui kepatutan sosial, eksistensi immateriil yang dicapai dalam jiwa keseimbangan. Dalam suatu perjanjian, kepentingan individu dan masyarakat akan bersamaan dijamin oleh hukum objektif. Perjanjian dari sudut substansi atau maksud dan tujuan ternyata bertentangan dengan kesusilaan dan atau ketertiban umum akan batal demi hukum dan pada hakekatnya hal serupa akan berlaku berkenaan dengan perjanjian yang bertentangan dengan undang-undang. Dengan ini jelas bahwa kepatutan sosial tidak berwujud melalui perjanjian demikian. Dalam perjanjian yang tidak seimbang bisa muncul

${ }^{33}$ John Rawls, A Theory of Justice, Oxford: University of Press, 1992, hal. 549. hal. 549. sebagai akibat perilaku para pihak sendiri ataupun sebagai konsekuensi dari substansi (muatan isi) perjanjian atau pelaksanaan perjanjian.

Berkaitan dengan isi atau maksud dan tujuan perjanjian para pihak memperluas dengan meningkatkan pengharapan untuk mencapai prestasi yang dipercayakan. Dari landasan pemikiran para pihak dapat diketahui bilakah pengharapan di masa depan dapat bersikap objektif ataukah justru mengandung pengorbanan pihak lawan yang berakibat sedemikian rupa sehingga pengharapan dimasa depan berujung pada ketidakseimbangan. Pencapaian keadaan seimbang mengimplikasikan dalam konteks pengharapan masa depan yang objektif, upaya mencegah terjadi kerugian salah satu pihak dalam perjanjian.

Dalam perjanjian timbal balik, kwalitas dari prestasi yang diperjanjikan timbal balik, akan dijustifikasi oleh tertib hukum. Kendati demikian, perjanjian harus ditolak seketika tampak bahwa kedudukan faktual salah satu pihak terhadap pihak lain adalah lebih kuat dan tidak seimbang, hal ini dapat mempengaruh cakupan muatan isi maupun maksud dan tujuan perjanjian. Sepanjang prestasi yang diperjanjikan bertimbal balik mengandalkan kesetaraan, maka bila terjadi ketidak seimbangan, perhatian akan diberikan terhadap kesetaraan yang terkait pada cara bagaimana perjanjian terbentuk dan tidak pada hasil akhir dari prestasi yang ditawarkan secara bertimbal balik. ${ }^{34}$

\footnotetext{
${ }^{34}$ Herlien Budiono, Azas Kesimbangan Bagi Hukum Perjanjian Indonesia, Op.Cit., hal. 318.
} 
Permasalahan yang timbul dalam perjanjian, pengambilan putusanputusan maupun ketetapan pengadilan haruslah dilandasi : kesusilaan yang baik (de goede zeden), konstruksi itikad baik (goede-trouw constructie), kewajaran dan kepatutan (redelijke en billijkheid), penyalahgunaan keadaan (misbruk van omstandigheden) dan justum pretium, sebagai landasan yang mengandung semangat atau jiwa keseimbangan. Jika hakim mengetahui ada penyimpangan yang terlalu jauh tatkala menguji perjanjian terhadap kepentingan umum atau terhadap kepentingan salah satu pihak yang berkehendak mempertahankan perjanjian, konsekuensi dari putusan hakim harus diterima semua pihak. Hukum tidak memberikan kepastian lebih daripada kepastian akan memberi perlakuan sama terhadap kondisi serupa, yang sama diperlakukan sama, yang berbeda akan mendapat perlakuan berbeda, bagaimana keseimbangan tercapai adalah persoalan lain.

Pencapaian keseimbangan kepatutan immateriil (immateriele gezindheid) adalah suatu tujuan yang menjadi landasan pembenar perjanjian. Untuk itu mesti ada syarat-syarat tegas yang mengatur akibat hukum yang terjadi akibat tidak ada keseimbangan. Dari titik tolak ukur adanya ketidakseimbangan dalam segala situasi dan kondisi, harus ada aturan baku untuk batasan atau ruang lingkup ketidakseimbangan harus ditetapkan. Namun, mencari dan menemukan tolak ukur yang baku untuk menetapkan ada atau tidak adanya suatu situasi ketidakseimbangan

merupakan

masalah tersendiri.

Perjanjian memiliki sejumlah aspek yaitu perbuatan para pihak, isi perjanjian yang disepakati para pihak, dan pelaksanaan perjanjian. Tiga aspek yang saling berkaitan dari perjanjian di atas dapat dimunculkan sebagai faktor penguji berkenaan dengan daya kerja asas keseimbangan. ${ }^{35}$

Hal yang sama juga dikemukakan oleh Mariam Darus Badrulzaman yang mengatakan bahwa suatu perjanjian memiliki sejumlah aspek yaitu perbuatan para pihak, isi perjanjian, dan pelaksanaan perjanjian yang telah disepakati para pihak tersebut. Tiga aspek yang saling berkaitan dari perjanjian tersebut dapat dimunculkan sebagai kriteria berkenaan dengan syarat adanya keseimbangan, tetapi juga menjadi kriteria adanya ketidakseimbangan jika syarat-syarat keseimbangan dan tiga aspek tersebut tidak dipenuhi. ${ }^{36}$ Kemudian, Mariam Darus Badrulzaman maupun Salim H.S., menyebutkan bahwa asas keseimbangan yaitu suatu asas yang menghendaki kedua belah pihak untuk memenuhi dan melaksanakan perjanjian itu. Asas keseimbangan ini merupakan kelanjutan dari asas persamaan, dimana kreditur mempunyai kekuatan untuk menuntut pelunasan prestasi melalui kekayaan debitur, namun kreditur memikul pula beban untuk melaksanakan perjanjian itu dengan itikad baik, sehingga

${ }^{35}$ Cahen, J.L.P., Misbruik van omstandingheden, serie privaatrechtelijke begrippen, Arnhem: deel 15, 1983, hal. 11-20.

${ }^{36}$ Anita Kamilah, Op.Cit., hal. 106. 
kedudukan kreditur dan debitur seimbang. ${ }^{37}$

Merujuk pada ketiga aspek perjanjian yang dijadikan dasar adanya keseimbangan tersebut, maka secara garis besar dapat dikelompokkan pada tiga fase, yaitu: ${ }^{38}$

1. Fase prakontrak/perbuatan para pihak yang melakukan perjanjian. Agar suatu perbuatan para pihak dapat menimbulkan akibat hukum, maka perbuatan hukum dapat dilihat dari dua kategori perbuatan, yaitu:

a. Penyataan kehendak dan orang yang berbuat atau bertindak dalam melakukan perbuatan hokum,

b. Kewenangan hukum dan kecakapan bertindak (handelings bevoegdheid en handelingsbekwaamheid).

2. Fase kontra atau perjanjian yaitu dalam bentuk isi kontrak yang disepakati para pihak. Isi kontrak merupakan prestasi/objek perjanjian yang telah disepakati oleh para pihak, baik secara tegas maupun diam-diam.

3. Fase Pasca kontrak/Pelaksanaan isi perjanjian yang telah disepakati. Para pihak selayaknya memenuhi suatu perjanjian dengan itikad baik, sehingga tujuan penutupan perjanjian bagi para pihak untuk mendapatkan keuntungan secara timbal balik dapat diwujudkan. Keseimbangan tidak mutlak harus dilandasi untung rugi dalam arti materil, tetapi prinsip keseimbangan ini harus dipahami dalam arti "tercapainya atau

37 Mariam Darus Badruizaman, Aneka Hukum Bisnis, Op.Cit., hal. 43; dan Salim H.S., Hukum Kontrak Teori Dan Teknik Penyusunan Kontrak, Op. Cit., hal. 13-14.

${ }^{38} \mathrm{Ibid}$, hal. 36. terpenuhinya" semua tujuan dari perjanjian, yaitu tercapainya eksistensi immateril, sehingga memungkinkan berfungsinya mekanisme kontrak secara seimbang, dilihat dan cara terbentuknya perjanjian itu sendiri. ${ }^{39}$

Akan tetapi dalam praktiknya sekarang ini, Indonesia sebagai negara hukum belum bisa memberikan keadilan secara merata. Banyak para pencari keadilan merasa tidak puas dan kecewa. Dalam penerapan hukum oleh penegak hukum di Indonesia saat ini, seringkali para penegak hukum menjalankan tugasnya tidak sesuai dengan aturan yang ada.

Untuk mengatasi hal tersebut maka setiap permasalahan yang timbul dalam hal ini permasalahan dibidang perjanjian haruslah diselesaikan dengan peraturan yang berlaku dengan memperhatikan syarat-syarat sahnya perjanjian, asas-asas atau prinsip-prinsip dalam hukum perjanjian. Salah satunya dengan menerapkan asas keseimbangan bagi para pihak secara seimbang. Dengan demikian diharapkan penerapan hukum yang ideal dan dikehendaki dapat terwujud.

\section{PENUTUP}

\section{Kesimpulan}

1. Hal-hal yang harus diperhatikan atau dipenuhi untuk mewujudkan tercapainya tujuan suatu perjanjian: Sistem pengaturan hukum perjanjian; Asas hukum perjanjian; Syarat sahnya suatu perjanjian; Bentuk dan jenis-jenis

${ }^{39}$ Herlien Budiono, Azas Kesimbangan Bagi Hukum Perjanjian Indonesia, Op.Cit., hal. 349, 471. 
perjanjian; Istilah dan ketentuan yang harus diperhatikan dalam pembuatan perjanjian; Hal-hal yang harus diperhatikan dalam pembuatan/ penyusunan perjanjian; Prinsip-prinsip dalam penyusunan kontrak; Struktur dan anatomi perjanjian; Bentuk-bentuk penyelesaian sengketa; Berakhirnya Perjanjian dan Tujuan pembuatan perjanjian.

2. Dalam perjanjian dikenal asas keseimbangan, yang artinya setiap orang yang membuat perjanjian harus dilakukan dengan asas keseimbangan. Asas-asas utama dianggap sebagai soko guru hukum perjanjian, memberikan sebuah gambaran mengenai latar belakang cara berpikir yang menjadi dasar hukum perjanjian. Asas keseimbangan adalah suatu asas yang dimaksudkan untuk menselaraskan pranata-pranata hukum dan asas-asas pokok hukum perjanjian yang dikenal dalam hukum perdata yang berdasarkan pemikiran dan latar belakang individualisme pada suatu pihak dan cara pikir bangsa Indonesia pada lain pihak.

Dalam suatu perjanjian, kepentingan individu dan masyarakat akan bersamaan dijamin oleh hukum objektif. Merujuk pada ketiga aspek perjanjian yang dijadikan dasar adanya keseimbangan tersebut, maka secara garis besar dapat dikelompokkan pada tiga fase, yaitu: Fase prakontrak/perbuatan para pihak yang melakukan perjanjian; Fase kontra atau perjanjian ; Fase Pasca kontrak/Pelaksanaan isi perjanjian yang telah disepakati.

\section{Saran}

1. Para pihak yang hendak melakukan perjanjian harus benar-benar memahami betapa pentingnya asas keseimbangan dalam pembuatan dan pelaksanaan perjanjian.

2. Apabila timbul masalah yang berhubungan dengan perjanjian, diharapkan hakim yang menangani tidak semata-mata mengedepankan asas pacta sunt servanda tetapi harus memperhatikan asas- asas lain terutama keseimbangan.

\section{DAFTAR PUSTAKA}

\section{A. Buku}

Anita Kamilah, Bangun Guna Serah (Build operate and Transfer/ BOT) Membangun Tanpa Harus Memiliki Tanah (Persfektif Hukum Agraria , Hukum Perjanjian dan Hukum Publik), Bandung: CV Keni Media, 2013.

Atiyah, P.S., An Introduction to the Law of Contract, 5th. Ed., New York: Oxford University Press Inc, 1995.

Cahen, J.L.P., Misbruik van omstandingheden, serie privaat rechtelijke begrippen, Arnhem: deel 15, 1983.

Duane R. Monette Thomas J. Sullivan, Cornell R. Dejong, Aplied Social Research, Chicago, San Fransisco: halt, Reinhart and Winston Inc. 1989

Friedman, M. Lawrence, American Law An Introduction, penerjemah Whisnu Basuki, Jakarta: Tata Nusa, 2001.

Herlien Budiono, Het Evenwichtbeginsel Voor Het Indonesisch 
Contractenrecht, Diss Leiden, 2001.

..........., Asas Keseimbangan bagi Hukum Perjanjian Indonesia: Hukum Pejanjian Berlandaskan Asas-asas Wigati Indoonesia, Bandung: PT.Citra Aditya Bakti, 2006.

Huala Adolf, Dasar-dasar Hukum Kontrak Internasional, Bandung: Refika Aditama, 2006.

Johannes Ibrahim \& Lindawaty Sewu, Hukum Bisnis Dalam Persepsi Manusia Modern, Bandung: PT. Refika Aditama, Cetakan kedua, 2007.

Lubis, M Solly, Filsafat Ilmu dan Penelitian, Bandung: Mandar Maju, 1994

Mariam Darus Badrulzaman, Aneka Hukum Bisnis, Bandung: Alumni, 1994 dan tahun 1995.

Munir Fuady, Hukum Kontrak (dari Sudut Pandang Hukum Bisnis), Bandung: Citra Aditya Bakti,1999.

Rawls, John, A Theory of Justice, Oxford: University of Press, 1992.

R. Setiawan, Pokok-pokok Hukum Perjanjian, Bandung: Bina Cipta. 1987.

Salim H.S, Hukum Kontrak Teori dan Teknik Penyusunan Kontrak, Jakarta: Sinar Grafika, 2010.

Soerjono Soekanto, Penelitian Hukum Normatif, Jakarta: PT RajaGrafindo Persada, 2003.

Soejono Dirdjosisworo, Hukum Bisnis, Bandung: Mandar Maju, 2003, hal. 28.

Sri Gambir Melati Hatta, Beli Sewa Sebagai Perjanjian Tak Bernama: Pandangan Masyarakat dan Sikap Mahkamah Agung Indonesia,
Bandung: Alumni, cetakan ke2, 2000.

Sudikno Mertokusumo, Mengenal Hukum: Suatu Pengantar, Yogyakarta: Liberty, 1999.

Wacks, Reimon, Jurisprudence, London: Blackstones Press Limited , 1995.

\section{B. Peraturan Perundang-undangan}

KUHPerdata (burgelijk wetboek), diterjemahkan oleh R. Soebekti dan R. Tjitrisadibio, Jakarta: Pradya Paramita, cetakan 8, 1976.

\section{Kamus / Ensiklopedia}

Campbell Black, Henry, Black Law Dictionary, Sixth Edition, West Publishing Co., St. Paul Minn, 1990 